\title{
Perspective merit system on placement regulation of high level official civil servants (a Case Study of placement civil servants in Local Government on Palembang)
}

\begin{abstract}
Andy Fefta, WIJAYA, Department of Public Administrative Science, Faculty of Administrative Science, Brawijaya University, Malang, East Java, Indonesia andyfefta_fia@ub.ac.id Rizki, KARTIKA, Doctoral Program of Administrative Science, Faculty of Administrative Studies, Brawijaya University, Malang, East Java, Indonesia rizkikartika77@gmail.com Soesilo, ZAUHAR, Department of Public Administrative Science, Faculty of Administrative Science, Brawijaya University, Malang, East Java, Indonesia soesilozfia@ub.ac.id

Mardiyono, MARDIYONO, Department of Public Administrative Science, Faculty of Administrative Science, Brawijaya University, Malang, East Java, Indonesia mardiyn_fia@ub.ac.id
\end{abstract}

\begin{abstract}
Meritocracy is a contingent concept that depends on what people consider to be good in society. This research conducted shows that the principles of high-ranking officials of civil servants, especially in the local / city government. Therefore, need a new regulations for perspective placement, in order to minimize political and subjective interests in the field. Method of the research used a qualitative approach, qualitative inquiry. This method was chosen because researchers want to obtain a complete and holistic the phenomenon that occurs in this research. Researchers used a spiral data analysis model more suitable to do than a linear analysis model. Result of this study showed the community or public in general does not care too much about who becomes an official within the local government. The community or public in general are more focused on the figure of the Regional Head who is the leader in the local government and responsible for the public services. The Regional Head will change periodically, which results from a complicated political negotiation process. Therefore, these high officials, regardless of who the Regional Head is, must be the best officials resulting from a good selection process. The application of the merit system in the regulation of the placement of high-ranking officials of civil servants is a necessity and a joint task of all parties, including the community itself.
\end{abstract}

Keywords: Civil servants, Local government, Meritocracy, Politic, Regional Head

JEL Classification: $\mathrm{H} 1, \mathrm{H} 11, \mathrm{H} 7$ 


\section{Introduction}

The practice of the appointment and placement of the high officials of civil servants, which are found in various municipal or local governments, such as those in the Palembang local government, basically refers to a number of regulations that provide various provisions related to mechanisms and procedures that must be taken to appoint and place high officials of civil servants. Some sources of regulation are Government Regulation No. 11 of 2017 concerning Management of the Civil Servants, Constitution or Law No. 5 of 2014 concerning State Civil Apparatus (Civil Servants), or the Decree of the Minister of Home Affairs No. 16 of 2003.

Various regulations and decisions of the authorities indicate that the practice of appointing and placing the high officials of civil servants is a matter that must be taken seriously. Placement of high officials is not merely a matter of filling the empty organizational structure, but also related to the issue of institutional governance, development of human resources, building work culture, and others, which in turn will have an impact on productivity or performance of the relevant government institutions. The existence of civil servants or state civil apparatus at certain institutions, after going through a complex placement process, has a mission and objectives related to the interests of the institution concerned. This has not been added to the issue of the adequacy of the civil servants and the need for human resources to fill certain positions within the government that are also urgent. Therefore, the existence of regulations that provide clear provisions and procedures such as this is very necessary.

The regulation that arranges in detail about this placement also shows that the existence of human apparatus in the context of government institutions is very important. Humans are the core of the organization. The State Civil Apparatus, regardless of class and position, is at the core of existing government institutions. The advance and withdrawal of public institutions will greatly depend on the presence of personnel or apparatus. If the institution concerned can seriously empower its human resources, whether through development, learning, training, motivation, compensation, promotion or career development activities through placement practices, the institution can also develop and produce good public services.

There are various literatures based on research by management experts who state that placement practices have a significant impact on human resources management. The practice of placement is a practice that is included in the basic series of human resource management work in an organization that starts from analyzing organizational needs, analyzing positions and workloads, setting goals 
and objectives, recruitment and selection, to placing human resources in positions that suit their abilities and their expertise. This pattern is a common standard in managing human resources which in turn will determine the overall performance of the organization. Decenzo and Robbins (2010, p. 114) for example explain that this placement is an action to bridge the need for structure fulfilment with existing human resources (people). There are provisions regarding work or jobs that must be completed and who is responsible, in which the existing workforce will be adjusted for their abilities and expertise with the jobs. If there is a mismatch between the ability and expertise of human resources and the existing work, then the management of an organization will be difficult to achieve its strategic goals and objectives.

In the context of the placement of high officials of civil servants, such as those found in the Palembang local government, the regulations underlying the mechanism, not only refer to modern management theories, but also based on merit interests in government institutions. A high official who will be placed in a particular field is the result of a lengthy mechanism that involves the practice of establishing a Selection Committee, planning for placement, application, selection, assessment, and determination by the authorized Personnel Development Officer (PPK).

These are the steps that are made to ensure that merit principles, such as openness, fairness, competency-based selection, can be applied properly and correctly in the process of placing the state high officials. The application of merit is to ensure that this process can produce the best apparatus in its position. While existing regulations are the legal basis so that in this process, civil servants, especially high-ranking officials, do not take actions that are contrary to the application of merit principles in particular, and bureaucratic reform in general.

\section{Theoretical Review}

\subsection{Theory of Meritocracy}

Meritocracy can basically be seen as a degree of specificity, both broad and narrow, which will therefore lead to a variety of understandings. Meritocracy can be interpreted specifically, but it can also raise deeper questions, such as: how is meritocracy defined? Who defines it? What is the process of formulation? Where is it applied? What are the norms, values, and principles, if any, related to them? Therefore, Donald Low $(2014$, p. 49) in this case states: “...that there are varieties of meritocracy, some desirable, others possibly malignant. The debate should not 
be over whether we embrace meritocracy or not; rather, it should be over the kind of meritocracy we want."

Amartya Sen (in Kenneth Arrow, et. Al., 2000, pp. 5-6), states that meritocracy is a contingent concept that depends on what people consider to be good. He wrote: “...meritocracy, and more generally the practice of rewarding merit, is essentially underdefined, and we cannot be sure about its content - and thus about claims regarding its justice." Because of this, before any further explanation about merit, merit actions cannot be judged separately from an understanding of the good that exists in society. In other words, if meritocracy is a system to give merit, then how merit is defined will be important in its implementation.

However, while considering things that are deeply related to the concept of meritocracy, at the same time we can also see meritocracy in general understanding: a social system in which merit or talent is the basis for choosing and placing people in positions and give them wages based on this. In government institutions based on merit, everyone has equal and equal rights and opportunities to get rewards based on their efforts and competencies regardless of gender, race, social class, religion, or other non-merit factors.

The application of the concept of meritocracy is actually intended to strengthen fairness and balanced competence, especially because it rejects patronage, nepotism, corruption, and incompetence in public service. Meritocracy is a system that emphasizes fair and healthy competition, open selection, critical evaluation of one's quality, and the importance of qualification standards in a good recruitment process. In this merit system, individual designation of certain personnel is considered as a bad and inappropriate step to determine one's position. A person is only considered eligible to occupy a certain position if he has the qualifications and qualities that are in accordance with the needs of the organization. Therefore, the application of the principle of meritocracy today, both in public and private institutions, generally will be related to the test of eligibility, educational qualifications, and an accurate database of one's competence for positions offered openly. Some studies of meritocracy show the following:

- Evans and Rauch (1999) state that state bureaucracies characterized by meritocratic recruitment, which are generally associated with a combination of education and due diligence, may contribute to economic growth.

- Recruitment with the implementation of a good merit system can also reduce corruption. Studies conducted by Dahlstrom, Lapuente, and Teorell (2012) in 52 countries, show that bureaucracy with this system can reduce corruption 
because it creates a separation between the interests of bureaucrats and politicians. However, it should be noted that the reduction in corrupt behavior is not because the elected bureaucrats are based on the merit system better than the politicians appointed to occupy certain positions, but because both are indeed different types.

- Sumedh Rao (2013) states that the application of this merit system can attract educated people to enter the field of public services and government institutions, especially those who have the intention to improve existing services. This in turn may be able to improve many things related to the existence of public institutions or the government itself. Those who get certain positions based on their capabilities, not because of certain "political orders", will find it easier to work and produce innovative ideas, than those who occupy certain positions in ways that are not based on a merit system.

The logic of the merit system is that each position requires the right person, with the level of expertise and competence that supports alignment with the needs of the position, so that the performance goals of the service can be achieved properly. This means applying the principles of meritocracy at every level of work. Starting from promotion, initial recruitment, candidate selection, evaluation, to the placement of candidates.

The application of these principles and systems is certainly needed in the context of government and or bureaucratic institutions. When a bureaucrat or an official at a certain position is chosen and placed based on his competence, the possibility of increasing public services is also higher. A different situation will occur if an official appointed to occupy a certain position is the result of a process of bargaining or political negotiations. Officials who occupy certain positions may be apparatuses who do not have competencies related to the position they occupy. This condition not only hinders the improvement of the performance of government institutions, but also disrupts overall public services.

Although it looks simple, the application of meritocracy actually has its own difficulties. Willy McCourt $(2007$, p. 5) states that merit can be defined as the appointment of the best person for any given job'. This statement of merit may implies several important principles:

- Merit must be applied at every level of the organization and management process (jobs at every level); meritocracy does not mean the calculation of mere salary or wages, but it must be applied when the organization carries out the recruitment process. 
- Meritocracy must be able to get the best candidate; everyone has the same rights and opportunities to get a job and fill a certain position in accordance with the capabilities they have.

- Open to all; there must be no internal agreement or limited to certain groups;

- Systematic, transparent, and challengeable; meritocracy means the efforts of institutions to improve themselves sustainably, seeing that even unsuccessful candidates can become feedback for making better decisions in the future (UNDP, 2015, p. 9).

To achieve the desired aspects of the merit system implementation in a public institution, there must be an ethical framework and a check and balance system, especially by ensuring the following elements:

- Identification and publication of the complete list of positions that are considered political in nature.

- Clear procedures for recruitment and promotion, ensuring transparency in the selection process and inclusion of formal checks and balances and appeals in the case of arbitrary action.

- Restricted discretionary powers of politicians over selection processes (short-listing of candidates should be the sole responsibility of a pluralistic selection panel).

- A code of conduct that stresses the political neutrality and loyalty of the civil servants.

- Constitutional and legal guarantees (Civil Service Act) stressing the right of candidates for (non political) public employment, not to be discriminated against because of their gender, ethnic origin, political, economic, religious, philosophical, cultural or social opinions or conditions. (UNDP, 2004, pp. 12-13, see also UNDP, 2015, p. 9)

The phenomenon of meritocracy in the context of government and public administration in general, as an effort to get the best people to occupy positions in accordance with their capabilities and capabilities, is not an easy thing to do.

This requires the existence of a selection system and stages of good empowerment, so that people who are candidates to occupy certain positions can have various competency categories defined. However, the application of merit principles in the practice of appointment and / or placement, especially the high officials of civil servants, is an urgent need that must be met. 
The application of meritocracy in the practice of appointing and placing the high official of the civil servants may be able to ensure the presence of the best people that are in line with their fields of expertise, which in turn will have an impact on their performance. High officials who occupy positions through a fair placement process based on open selection results will also reduce negative things that often arise in the practice of overall governance.

\section{Research Method}

The approach used is a qualitative approach, qualitative inquiry. This approach was chosen because researchers want to obtain a complete and holistic the phenomenon that occurs in this research. Qualitative approaches were also chosen with the consideration that this approach offers more flexibility and freedom for researchers to use a variety of tools that can assist researchers in understanding the phenomenon without having to be limited by a particular metatheory or narrative. Uwe Flick(2009, p. 12) in this case states that: "Qualitative research is specific relevance to the study of social relations, due to the fact of the pluralization of life worlds."

In this context, then this research like as generally qualitative research, a method that is more often used is a method that is explaining and analyzing the objects researched, so that researchers can get the depth and meaning of the research they do. In that case, the researcher chose a qualitative and descriptive method for this research so that it could describe the phenomenon thoroughly that was researched. The selection of descriptive and holistic methods by researchers is considered to help researchers in describing various social contours and processes that occur in the context of popular culture as a social reality that surrounds and influences the practice of bureaucracy and work culture found in government institutions.

In this study researchers used a spiral data analysis model more suitable to do than a linear analysis model. The use of the spiral model itself is because researchers are more able to photograph the phenomena that exist more intact. Through this spiral method, researchers can read data in a more structured way, because of the management process and data specifications, which later can facilitate authors to find relationships between data, the context behind it, and the final results it displays. 
The use of this spiral model also makes the researcher more objective in describing the reality and / or phenomenon under study, and can produce a visualization of phenomena that are examined more clearly in the presence of systematic analysis procedures.

This spiral data analysis model has a procedure that starts from the data management process (data managing), followed by a whole reading process of data (reading and memoing), then provides a description and classifies the data, as well as interpreting the data (describing, classifying, interpreting), and ends with representation or visualization of data (representing, visualizing). Everything is integrated as part of the author's learning process to get in-depth research results and conclusions. In the chart:

Figure 1. Qualitative Inquiry \& Research Design, Choosing Among Five Approaches

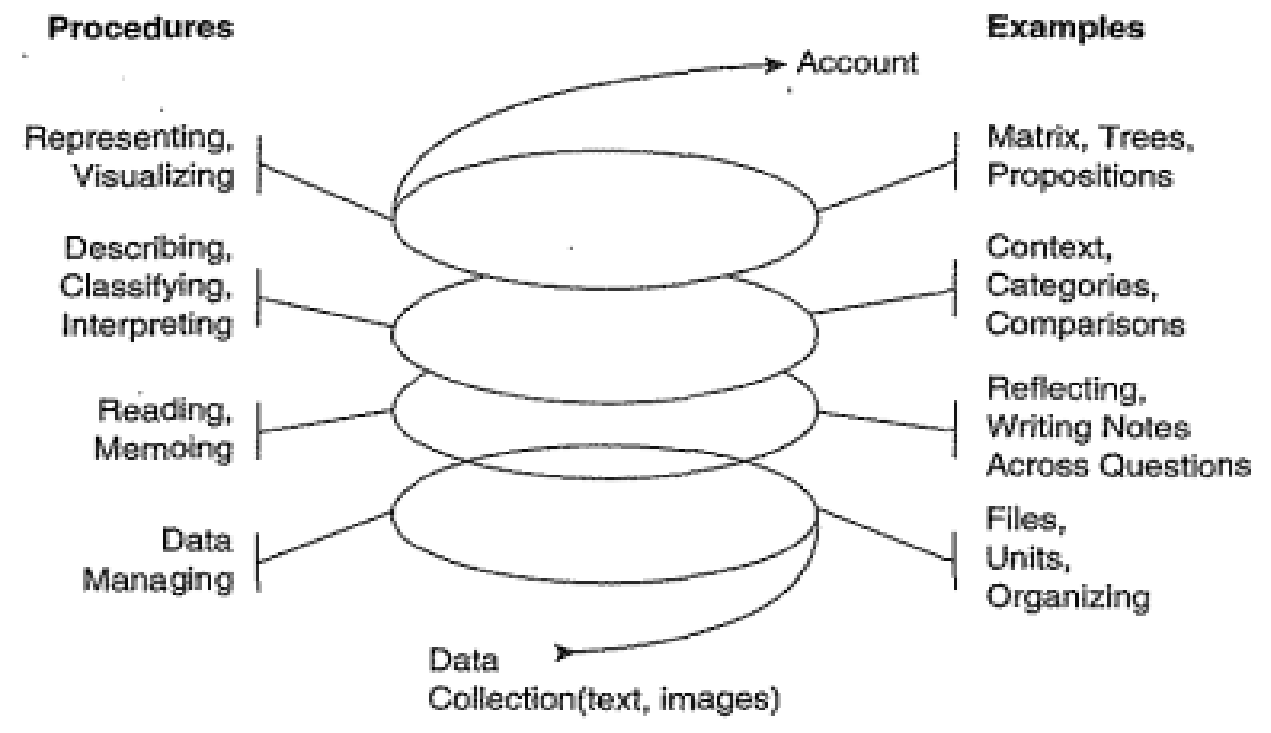

Source: John W. Creswell, 2007

\section{Results and Discussions}

4.1 Merit's Perspective on The Regulation of Placement of Civil Servants In Palembang Local Government

The need for the application of meritocracy in the practice of appointing and placing the State Officials of the High Civil Service can of course only be fulfilled 
through the regulation of placement that regulates this matter. This regulation is very important, considering that it is the legal basis for the practice of placing High Officials with certain mechanisms that present the principles of merit in them. The placement mechanism based on merit is carried out by, for example, forming a Selection Committee that involves professionals to analyze the feasibility of candidates and to test them fairly and openly.

However, based on the results of research conducted, the existing regulations are basically still overlapping, especially because the enactment of one regulation does not automatically cancel the previous regulations, even though there are certain technical contradictions. Government Regulation No. 11 of 2017 for example, expresses firmly that the appointment and placement of State Official High Officials must go through the Selection Committee with procedures that include planning, opening applications, selection, assessment, announcements, until stipulation by the PPK (Personnel Development Officer) to then be appointed and placed in the position that has been projected on each candidate. Government Regulation No. 11 of 2017 concerning Management of the State Civil Apparatus (Civil Servants), Article 114, states that the formation of the Selection Committee is the second step after the formulation of the High Leadership Position (Jabatan Pimpinan Tinggi) to be filled. This Selection Committee was formed by Personnel Development Officer (PPK), especially for Madya Officials and Pratama Officials, and was formed by the President for certain Madya Officials.

While the Decree of the Minister of Home Affairs No. 16 of 2003 states that the Regional Head or City Mayor can appoint and place certain high officials without having to go through a mechanism involving the Selection Committee or only through Baperjakat (Position and Grade Consideration Board). The Decree of the Minister of Home Affairs No. 16 of 2003, Article 4 states that related to procedures for consulting the appointment and dismissal of local or City Regional Secretaries and Echelon II Structural Officials in the local or city Government, the Regents or Mayors can consult in writing the names of prospective Echelon II structural officers in the local or city government to the Governor based on the proposal of the local or city Mayor after receiving consideration or official text from Baperjakat.

If within 30 (thirty) days after the receipt of the written consultation request there is no written response from the Governor, then the proposal of the Regent or Mayor regarding the appointment is deemed to have been consulted. In other words, the Regent or Mayor can make appointments and placements without having to go through the Selection Committee. 
There are two mechanisms that can be implemented legally, but these two mechanisms have different values, especially those related to efforts to implement the merit principle in the government bureaucracy. The first mechanism, contains a rigorous selection process that is regulated by the Selection Committee by involving certain assessments to ensure that candidates for High Officials projected to occupy certain positions or positions within the city government are candidates with personal qualifications and competencies that are in line with their job requirements. While the second mechanism, contains the placement rules without involving the Selection Committee, although this process involves consideration of Baperjakat regarding the candidates. The selection and assessment carried out are not entirely based on the principle of openness, which should be the main characteristic of government meritocracy.

The same mechanism can also be seen in the arrangement of government agency organizations, where the existing high leadership positions can be reduced or vice versa. The arrangement of high-ranking officials can be carried out through competency tests of officials available by the selection committee. If the arrangement of high-ranking officials does not obtain candidates for high-ranking officials who have competencies in accordance with the needs of the organization, then filling in the high leadership positions will be done through open selection.

This provision is contained in Article 131 of Law No. 5 of 2014 concerning the State Civil Apparatus, which states that the filling of vacant high-ranking positions through transfers from one high-ranking position to another high-ranking position can be carried out through competency tests of existing officials, and must be able to meet requirements such as: (1) officials who will be transferred are still in the same grade of classification; (2) fulfill grade competency standards; and (3) has held the related position for a minimum of 2 (two) years and a maximum of 5 (five) years.

The above regulation states that high-ranking officials can be selected and placed in certain departments or sections without having to go through the Selection Committee or be carried out openly. Open selection is only carried out when there are no candidates in accordance with the position qualifications or requirements that have been set. In other words, there is room for the Regional Head to replace and place high-ranking officials within his government without having to go through an open selection process. This type of placement mechanism, although on the one hand can reduce the costs and time used for a long open selection process, but on the other hand this practice actually does not represent merit values that exist in government institutions, especially for the process of selecting and placing high officials of civil servants. 
The application of the principles of justice, openness, competition, and qualification-based compensation as components of merit in all institutional activities related to human resources is a must. The placement mechanism that is carried out without going through an open selection process, but enough with a competency test for candidates who are considered to fulfill existing job qualifications, indeed still reflects the application of some merit values or principles. However, its closed implementation shows that such practices have not been fully based on existing merit principles.

In the context of the Palembang city government, there is a case where the Mayor of Palembang has appointed and placed several high-ranking officials and high-ranking leaders in the Palembang city government through this second mechanism. The Mayor of Palembang at that time, appointed several high officials to fill various positions within his government. In this case, the Mayor appointed 108 people consisting of echelon II, echelon III, and echelon IV officials based on Palembang Mayor's Decree No. 821.3/099/BKD.DIKLAT-V/2015 on November 3, 2015. The decision to appoint these officials in its continuation was considered problematic by KASN (State Civil Apparatus Commission).

KASN finally issued a recommendation letter No. 1390/KASN/12/2015 on December 4, 2015. The core of this KASN Recommendation Letter was 34 people were returned to their original positions. KASN also issued a second Recommendation Letter Number B-40/KASN/I/2016 containing recommendations for completing the appointment and dismissal of civil servants from and within the civil servants structural position within the Palembang city government on November 3, 2015. This letter was addressed to the Governor of Palembang, which means asking the Governor to participate in resolving the issue of the appointment and placement of High Officials within the Palembang city government. KASN also issued the third Recommendation Letter Number B49B$49 / K A S N / I / 2016$ on January 13, 2016. The letter stated that KASN provided an alternative to the Palembang city government in the form of an open auction for the Primary High Leadership Position without dismissing.

Based on the KASN recommendation, echelon II, III, and IV officials who had been elected and were appointed as high-ranking officials in the Palembang city government were later annulled and overhauled through an open auction mechanism in the Palembang city government. The open auction resulted in highranking officials and high-ranking officials currently in office. A review by KASN regarding the practice of placing High Officials in the Palembang city government in the above placement cases shows that the closed placement process is 
considered to be contrary to merit principles which is the goal of bureaucratic reform within the government itself.

However, based on the rationalization of the needs of government institutions regarding this placement process, the existing statutory provisions relating to the appointment and placement of high officials of civil servants in the local government, which are also applied in the Palembang city government, generally contain principles and merit values. The application of merit values for example can be found in the terms of appointment of high-ranking officials.

These terms states that the officials must be able to fulfill competency requirements as a prerequisite for them to be placed in certain positions. In addition, the existing regulation also states that high officials who occupy certain positions or grades must able to meet performance targets in accordance with existing employment agreements.

If the high officials cannot fulfill the performance demands as contained in the employment agreement, then he will be evaluated and asked to improve his performance within a certain time limit. However, if the official concerned as long as the time limit for the remedy given also cannot show an increase in performance, then he must take part in re-selection or competency re-tests.

Based on the results of the competency test or reassessment, the relevant official may be transferred to another position in accordance with the competencies possessed or placed in a lower position in accordance with the applicable laws and regulations. However, this practice, once again, has never been carried out professionally, considering that in many cases there are, although not always visible to the public, the existence of high officials in the context of rolling positions or existing placements is more influenced by political decisions.

An official who is proven to lack expertise in a particular field, and or has a mediocre performance report-to call it a failure-may be placed by the Regional Head in that particular area, insofar as it does not violate existing regulations, and which can certainly support the political interests of the Regional Head concerned or certain patronage behind it.

Therefore, certain regulations are needed that can identify and regulate a list of positions or grades that are considered to have political interests so that the meritocracy of the placement of the high officials of civil servants can be enforced. Without these regulations, there will be many gaps that can be played by the Regional Head in particular, to place people based on political decisions and not merely administrative considerations. 
Other issue that can be found in the regulation of the placement of high officials of civil servants in the local or city government, is the authority of the Regional Head or Mayor in the practice of such placement. In Government Regulation No. 11 of 2017 concerning Management of the State Civil Apparatus (civil servants), Article 114, states that the Selection Committee for the appointment and placement of high officials or high-ranking leaders is formed by the PPK (Personnel Development Officer) or the relevant Regional Head (Regent, Mayor).

In other words, the Regional Head or in this case, the Mayor, is the person who initiated the formulation of the Selection Committee. When the Mayor wants to do a rolling position, or replace the high officials within his government, then the Mayor will initiate the formation of the Selection Committee and consultate with relevant parties, especially KASN (National Civil Apparatus Commission).

At this point, the Mayor will explain the purpose of the replacement action plan or reform the composition of the high official apparatus in his government to KASN. If KASN considers that the Mayor's plan has a rational basis for its implementation, such as for improving the performance of regional apparatus organizations, then the formation of a Selection Committee begins. People who will fill the Selection Committee are selected based on the composition of the Law or regulation. However, the role of the Mayor in the selection of members of the Selection Committee cannot be underestimated. In other words, the membership of the Selection Committee can be fulfilled by certain people who can formally represent the interests of the Mayor to carry out the process of placement of the high officials in accordance with the subjective interests of the Mayor.

Judging from the framework of the merit system, the intervention of the Mayor in the formation of the Selection Committee actually contains certain biases that, although not explicitly seen, have the potential to injure the values or principles of merit itself. It is true that the Mayor has certain interests and missions in the practice of reforming the ranks of officials in carrying out government duties. Such actions must sometimes be considered reasonable considering that someone can only carry out the task well and effectively if he is assisted by people he believes in or has the same view of what he has to do. However, the Mayor is a government actor born of a long political process and involves many parties.

There are many forms of negotiations that occur and it will affect various decisions in their policies, especially those relating to the placement of certain high ranking officials within the government. Therefore, if a government leader in a region, such as Palembang Mayor in this case, has a legal space and the 
opportunity to choose people whom he considers in line with the interests of his government, then that decision cannot be blamed or taken for granted.

However, based on merit's own considerations, an action carried out based on patronage, nepotism and incompetence, especially in the context of governance that has a major impact on public service or the fate of many people, cannot be justified. Everyone, in the merit system, regardless of gender, ethnicity, religion, socio-cultural background, political choice, and others, has equal rights and opportunities to occupy certain positions as long as he is competent and can fulfill the required qualifications. Openness and fair competition, critical evaluation, fulfillment of professional standards and qualifications, must be the main consideration in choosing someone to occupy a certain position. If there was subjectivity and high political patronage interests in the practice of placing high officials within the government itself, then how to present healthy and open competition for everyone?

This problem must finally be resolved, especially to balance the professional needs based on merit with the personal interests of government leaders, especially the Mayor, in appointing and selecting their assistants. In other words, the authority and role of the Mayor in terms of the formation of the Selection Committee must have clear boundaries and be strictly regulated in a form of regulation that does not provide space or loopholes for scheming. The Mayor, for example, only initiates the formation of Pansel as a legal way to facilitate the interests of his government regarding the replacement and / or overhaul of the composition of the high officials in his government.

The rest, it is the responsibility of other neutral parties, such as KASN, where the selection of members of the Selection Committee is purely based on professional judgment and competence, so that they can work objectively, transparently and accountably. In this way the Selection Committee is expected to be able to capture the best people or candidates to fill vacant positions or in order to change the positions in the structure of the city government.

This ideal condition certainly presupposes certain prerequisites such as the professionalism of each party, awareness and ability to get rid of other interests besides professional interests, as well as objectivity and neutrality of the authorities starting from government leaders (Mayor), KASN, to people who will later be appointed as the Selection Committee.

The Mayor also has authority in the practice of appointing and placing the high official in the city government as the Personnel Development Officer (PPK), who has the right to choose one of the three names resulting from the candidate 
selection process conducted by the Selection Committee. Such rights are commonplace for leaders, especially in appointing people who are considered appropriate to assist them in running the government. Government leaders are not machines that do not have visionary considerations, work intuition, and personal reflection in looking at existing human resources.

Conversely, a good government leader must have these things because the world of government and public services requires certain human touches with which government bureaucracy and public services can meet diverse community needs. If government leaders cannot have space to choose people who are in line with their professional vision and intuition, the Mayor is only a meaningless position. Therefore, the authority to decide and determine the State Officials of the Civil Service who will be their assistants in carrying out the full functionality of public service institutions (government) is a necessary.

However, it can only be considered necessary, if the right to choose, decide, and place the Senior Official of the State Civil Apparatus owned by the Mayor, is carried out in a rational interest, and aims at providing quality public services. This authority is otherwise incorrect if it is actually used as a way to practice patronage politics, nepotism, or other purposes that are not related to professional interests and to improve the performance of government institutions themselves.

The authority of the Mayor as a PPK that has the authority to decide and ratify candidates is submitted through a selection process to then be placed in certain positions, becomes complicated in a merit perspective. The merit system on the one hand seeks to ensure the selection of an official through a fair competition, but on the other hand this system must not eliminate the freedom of leaders to realize personal considerations and political intuition in choosing officials.

This problem can actually be easier to solve if the candidate who have gone through a rigorous selection and assessment process, submitted by the Selection Committee to the Mayor as PPK, there is only one candidate, not three candidates as currently in accordance with statutory provisions. The single candidate is the selection participant who has the best value, so the Mayor as PPK has to ratify the candidate concerned only, without having to choose again based on considerations that are no longer fully professional.

If the results of the selection and assessment carried out by the Selection Committee produce three names of candidates, then the Mayor chooses and decides as PPK (Personnel Development Officer), it can be ascertained that the election has been based on the subjective views of the Mayor, not professional 
considerations. Professional considerations in this matter must be deemed completed through the selection and assessment process carried out by the Selection Committee.

Thus, the task of the Mayor as PPK (Personnel Development Officer) is ideally just to ratify the results of the selection and assign candidates with the highest scores as High Officials of the State Civil Apparatus to be placed in the agency or regional government agencies in the city government. The affairs of selection and assessment are fully the task of the Selection Committee. If the Mayor through this open selection process wants to place his people, then letting the selection system work is the best way to be fair and maintain the principle of merit from actions that can disturb it. If the people recommended by the Mayor turn out to be able to pass the selection with the best value, then it will be an advantage for the Mayor itself.

The Mayor does not only get a high official in accordance with his perspective, but also passes the test through a rigorous selection and assessment process, which means that the candidate is qualified and able to meet the competency standards or requirements needed for the position offered.

That condition certainly require new regulation that able to clearly provide a legal basis for its implementation. If so far the applicable regulations require the Selection Committee to recruit applicants for existing positions and select the three best candidates among them, then in the future, the name submitted by the Selection Committee to the Mayor as the PPK (Personnel Development Officer) that will validate the selection results, is only one candidate.

This new regulation needs to be formulated so that the principles of merit can be upheld in terms of the application of the authority of the Mayor regarding the process of placing high officials within the government. New regulation may be able to reduce the potential of political games in terms of the establishment and placement of high officials of civil servants, specifically within the Palembang city government.

\subsection{Regulatory Improvement based on Merit}

The practice of placing the high officials of civil servants, such as those in the Palembang city government, is generally carried out by referring to regulations as found in the following models: 
Figure 2. Placement of Primary High Officials in The Local Government

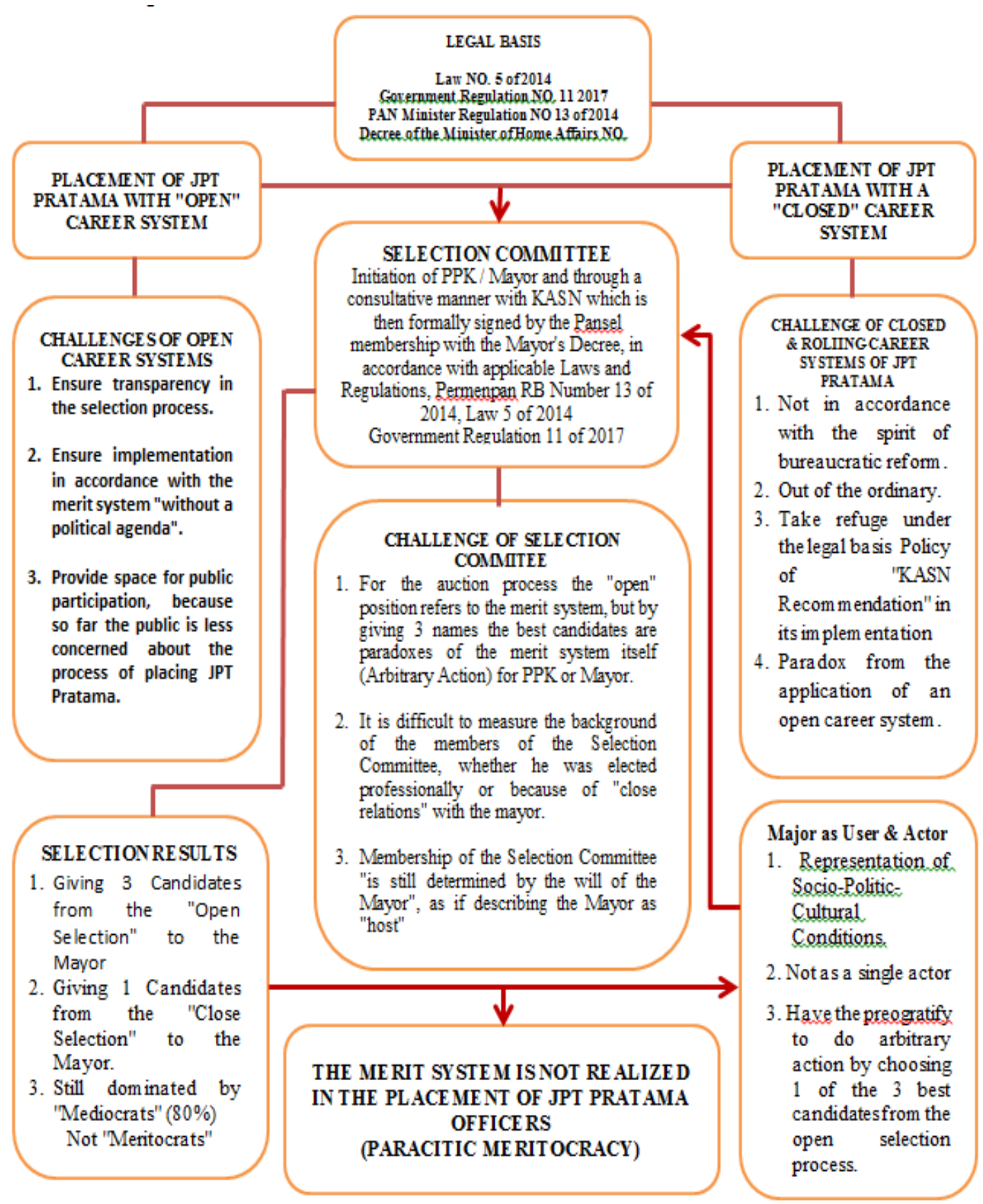


Based on the analysis, the existing model for regulation of the placement of high ranking officials has at least two fundamental issues, especially those related to merit:

- The mechanism for the appointment and placement of High Officials of the State Civil Apparatus, which can be implemented either with an open selection mechanism involving the Selection Committee or closed selection that does not involve the Selection Committee. The second mechanism that does not involve the Selection Committee is a representation of placement that is not based on merit interests.

- Authority of the Regional Head in placement practice, which allows subjective considerations to take precedence over merit-based considerations. The Regional Head forms a Selection Committee while deciding on one of the three candidates submitted to him subjectively.

Considering these issues, the improvement of regulations that are more adapted to the interests of merit is inevitable. This regulation based on merit is important to avoid the practices of the appointment and placement of State Civil Servants who are not based on merit principles, such as openness, equality, justice, competency-based selection, provision of equal opportunities, and honest evaluation. Therefore, the improvements needed for this are:

- Unification of regulations related to the mechanism for the appointment and placement of high official with reference to merit. The practice of placing highranking officials in this case, for example, must be carried out through an open selection mechanism carried out by the Selection Committee consisting of professional.

- Restrictions on the authority of the Regional Head (or Mayor) in the practice of the appointment and placement of the high officials as a whole. Improvements to this regulation for example can be done by limiting the authority of the Regional Head only in initiating the formation of the Selection Committee, but not participating in determining the people who are part of the Selection Committee. The Selection Committee in this case must be able to guarantee that the selection can produce the best candidates based on their competencies. The Regional Head then only has to appoint the best candidate resulting from the selection, and not make his own subjective decision.

Improvement of regulations related to the placement of high officials in the local or city government, requires a long process of formulating regulations involving many parties. However, if this needs can be met properly, especially by referring to the principles of merit, the placement of existing high officials can 
have a better impact on the performance of the bureaucracy and the government itself.

\section{Conclusions}

The placement practice of high officials is an activity in which, although commonly carried out within the government, is often ignored by the community. The community or public in general does not care too much about who becomes an official within the local government. The community or public in general are more focused on the figure of the Regional Head who is the leader in the local government and responsible for the public services. If the existing public services cannot meet the expectations of the community, then the Regional Head will be blamed. While high-ranking officials who are responsible and leading certain fields within the local government rarely get the spotlight.

This phenomenon is found in many local governments in Indonesia. In fact, the high-ranking officials are officials who continue to exist in the government and they also deal with the most public service affairs. The Regional Head will change periodically, which results from a complicated political negotiation process. However, the high officials of the state civil apparatus only change if there is a new policy from the Regional Head, and will quit if they have retired. Therefore, these high officials, regardless of who the Regional Head is, must be the best officials resulting from a good selection process. Based on this, the application of the merit system in the regulation of the placement of high-ranking officials of civil servants is a necessity and a joint task of all parties, including the community itself.

\section{References}

[1] McCourt, W. (2007). The Merit System and Integrity in the Public Service, Development Economics and Public Policy Working Paper Series. Paper, No. 20: 1-13. Institute for Development Policy and Management, University of Manchester.

[2] UNDP. (2015). Meritocracy for Public Service Excellence, Singapore: ACSH \& GCPSE.

[3] Creswell, J.W. (2007). Qualitative Inquiry \& Research Design, Choosing Among Five Approaches, Sage Publishing, London.

[4] Dahlström, C., Lapuente, V., \& Teorell, J. (2012). The Merit of Meritocratization: Politics, Bureaucracy, and the Institutional Deterrents of Corruption, Political Research Quarterly, 65 (3), pp. 656-668.

[5] Flick, U. (2009). An Introduction to Qualitative Research, 4th Edition, London: Sage Publishing.

[6] Sumedh, R. (2013). Civil Service Reform: Topic Guide. Governance and Social Development Resource Centre (GSDRC), Birmingham, UK: University of Birmingham. 
[7] Evans, P., \& Rauch, J.E. (1999). Bureaucracy and Growth: A Cross-National Analysis of the Effects of "Weberian" State Structures on Economic Growth, American Sociological Review, 64 (5).

[8] Sen, A. (2000). Merit and Justice, in Arrow, K., Bowles, S., \& Durlauf, S., (eds.) Meritocracy and Economic Inequality, Princeton, NJ: Princeton University Press.

[9] Low, D. (2014). Good Meritocracy, Bad Meritocracy, in Low, D., \& Vadaketh, S.T., Hard Choices: Challenging the Singapore Consensus, Singapore: NUS Press.

[10] Decenzo, D. A., \& Robbins, S. P. (2010). Fundamentals of Human Resource Management, New Jersey: John Wiley \& Sons, Inc.

[11] Government Regulation No. 11 of 2017 concerning Management of State Civil Apparatus.

[12] Law No. 5 of 2014 concerning State Civil Apparatus.

[13] Decree of the Minister of Home Affairs Number 16 of 2003 concerning Procedures for Consultation on the Appointment and Dismissal of the Provincial Regional Secretary, Regency / City Regional Secretary and Structural Official II in the Regency / City Government 